\title{
Distal acquaried demylinating symmetric neuropathy in two patients with essential hiperlgEmia
}

\author{
Neuropatia simétrica desmielinizante distal em dois pacientes com \\ HiperlgEmia essencial \\ Bruno Mattos Coutinho', Osvaldo José Moreira Nascimento², Marcos Raimundo de Freitas² \\ ${ }^{1}$ Mestre e Doutorando em Neurologia pela Universidade Federal Fluminense (UFF), Rio de Janeiro RJ, Brazil; \\ ${ }^{2} \mathrm{PhD}$, Fellow of the American Academy of Neurology (FAAN), Professor Titular em Neurologia da UFF, Rio de Janeiro RJ, Brazil. \\ Correspondence: Bruno Mattos Coutinho; Rua Visconde de Caravelas 70 / apto. 102; 22271-022 Rio de Janeiro RJ - Brasil; E-mail: bmcoutinho@gmail.com \\ Conflict of interest: There is no conflict of interest to declare. \\ Received 14 September 2011; Received in final form 21 February 2013; Accepted 28 February 2013.
}

Several rare cases of polyneuropathy have been described recently. There is a very large and differential diagnosis for polyneuropathy. Epidemiology of this condition is still not exact ${ }^{1}$.

We herein report two cases of a 67-year-old man and a 42-year-old woman with subacute progressive clinical picture of polyneuropathy and hyperIgEaemia. Those patients presented with similar symptoms, such as distal tetraparesis grade 4, generalized hyporeflexia, poor imbalance, decreased sensation of pain and temperature in the extremities, fine distal tremor and intense pain of the fingers of both hands and feet. Both showed more than $1000 \mathrm{ku} / \mathrm{L}$ of IgE in serum exams and have asthma. No other monoclonal gammopathy were found. The more common causes of polyneuropathy, like diabetes, hypothyroidism, B12 hypovitaminosis, infections like human T lymphotropic virus (HTLV 1 and 2), hepatitis $\mathrm{C}$ virus (HCV) and human immunodeficiency virus (HIV 1 and 2), were excluded, and there was no nerves enlargement in their physical exam. Nerve conduction studies revealed a conduction block amplitudes in motor (CMAP), lower terminal latency index (TLI) and alterations in sensory (SNAP) responses. In the first exam, we don't found SNAP responses, and the other electroneuromyography done showed small amplitude SNAP responses; prolongaded latency in nerves of upper limbs and both sural nerves were abolished (Table). Bilateral fibrillations or positives sharp waves were found in tibial anterior, gastronomies, paravertebral lumbar and cervical, gluteus medium, biceps and triceps. In both patients, the histologic features on sural nerve biopsy described no evidence of subperineurial or endoneurial edema or mononuclear inflammatory cell infiltrate in the epineurium or endoneurium. Those nerve biopsy describes mild loss of myelinated fibers and minimal axonal degeneration, and showed a slightly decrease number of thinly myelinated large caliber axons, with small onion bulb formations.

We suggest that IgE-mediated allergy may be one potential cause of distal acquired demylinating symmetric neuropathy (DADS) $)^{2}$. With research conducted in Pubmed and Google Scholar we only found one article related to polyneuropathy and hiperIgEmia. This other case described by Dr. Kimura et al. in 2005 shows a similar clinical picture, but with absence of sensory abnormalities ${ }^{3}$. Regular doses of rituximab $\left(375 \mathrm{mg} / \mathrm{m}^{2}\right)$ weekly in the first month and a single dose by month control power and pain of male patient. Only one cycle of intravenous immunoglobulin $(0.5 \mathrm{mg} / \mathrm{kg} /$ day) for five days do not demonstrated to be effective for female. The best pain treatment for female patient is using $60 \mathrm{mg}$ of oxycodon four times a day. Dysimmune neuropathy is an etiologically heterogeneous entity with diverse clinical presentations. Conventional treatment options, including corticosteroids, intravenous immunoglobulin, or plasma exchange, often fail to treat dysimmune neuropathies, such as chronic inflammatory demyelinating polyneuropathy, multifocal motor neuropathy and monoclonal gammopathy with its subtypes. Therefore, a significant percentage of patients require adjunctive immunosuppressive therapies. Currently, several monoclonal antibodies have been tested in open-label small-sized studies or even in single cases so as to establish future directions in the therapy of diseases of the peripheral nervous system ${ }^{4,5}$. 
Table. Electroneuromyography values from male and female patients.

\begin{tabular}{|c|c|c|c|c|c|}
\hline \multicolumn{6}{|c|}{ Male patient } \\
\hline Motor nerves & Latencies (ms) & Amplitudes (mV) & Velocities (m/s) & TLI & F waves (ms) \\
\hline \multirow[t]{2}{*}{ Fibular R } & 4.02 & 3.47 & & & \\
\hline & & 2.60 & 36.1 & 0.34 & \\
\hline \multirow[t]{2}{*}{ Tibial R } & 6.3 & 4.00 & & & \\
\hline & & 4.00 & 38.0 & 0.25 & \\
\hline \multirow[t]{2}{*}{ Fibular L } & 5.40 & 2.93 & & & \\
\hline & & 2.47 & 39.7 & 0.18 & 63.4 \\
\hline \multirow[t]{2}{*}{ Tibial L } & 4.44 & 4.07 & & & \\
\hline & & 0.10 & 29.4 & 0.38 & \\
\hline \multirow[t]{2}{*}{ Median R } & 8.16 & 3.57 & & & \\
\hline & & 2.00 & 40.0 & 0.15 & \\
\hline \multirow[t]{2}{*}{ Ulnar R } & 3.4 & 10.8 & & & \\
\hline & & 9.00 & 47.5 & 0.24 & 33.6 \\
\hline \multirow[t]{2}{*}{ Median L } & 7.02 & 6.00 & & & \\
\hline & & 6.02 & 48.1 & 0.11 & \\
\hline \multirow[t]{2}{*}{ Ulnar L } & 2.82 & 10.8 & & & \\
\hline & & 9.47 & 44.3 & 0.32 & 33.4 \\
\hline \multicolumn{6}{|c|}{ Female patient } \\
\hline Motor nerves & Latencies (ms) & Amplitudes (mV) & Velocities (m/s) & TLI & F waves (ms) \\
\hline \multirow[t]{2}{*}{ Fibular R } & 9.89 & 1.68 & & & \\
\hline & & 2.68 & 42.48 & 0.19 & \\
\hline \multirow[t]{2}{*}{ Tibial R } & 5.86 & 6.92 & & & 65.3 \\
\hline & & 2.02 & 46.61 & 0.28 & \\
\hline \multirow[t]{3}{*}{ Fibular L } & 8.18 & 1.66 & & & \\
\hline & & 0.61 & 34.22 & 0.25 & \\
\hline & & 0.35 & 61.22 & & \\
\hline \multirow[t]{2}{*}{ Tibial L } & 4.76 & 5.37 & & & \\
\hline & & 6.71 & 39.11 & 0.48 & 49.60 \\
\hline \multirow[t]{4}{*}{ Median R } & 5.86 & 8.26 & & & \\
\hline & & 6.11 & 29.41 & 0.29 & \\
\hline & & 0.63 & 34.24 & & \\
\hline & & 1.70 & 18.53 & & \\
\hline \multirow[t]{2}{*}{ Ulnar R } & 4.27 & 6.23 & & & \\
\hline & & 10.62 & & 0.36 & 33.25 \\
\hline Sensory nerves & Latencies (ms) & Amplitudes $(\mu \mathrm{V})$ & Velocities (m/s) & & \\
\hline Radial R & 5.49 & 1.45 & 18.21 & & \\
\hline Median R (first finger) & 5.25 & 5.05 & 19.04 & & \\
\hline Median R (third finger) & 4.88 & 4.94 & 20.49 & & \\
\hline Ulnar R (fifth finger) & 4.03 & 3.45 & 24.81 & & \\
\hline Sural R & 0 & 0 & 0 & & \\
\hline Sural L & 0 & 0 & 0 & & \\
\hline
\end{tabular}

Male patient: lower velocities in CMAPS and prolonged latencies in right and left medians and F waves. Lower values of Terminal Latencies Index $(T L I)(<0.30)$. No responses on SNAP values. Female patient: prolonged distal sensitive and motor latencies, some conduction block, prolonged latencies F waves, lower sensitive amplitudes and, again, lower TLI. In right median, we see conduction block in second inch. CMAPS: conduction block amplitudes in motor; SNAP: alterations in sensory; TLI: terminal latency index; R: right; L: left.

\section{References}

1. Martyn CN, Hugles RA. Epidemiology of peripheral neuropathy.J Neurol Neurosurg Psychiatry 1997;62:310-318.

2. Katz JS, Saperstein DS, Gronnseth G, et al. Distal acquired demyelinating symmetric neuropathy. Neurology 2000;54:615-620.

3. Kimura A, Yoshino H, Yuasa T. Chronic inflammatory demyelinating polyneuropathy in a patient with hyperlgEaemia.J Neurol Sci 2005;15:89-93.
4. Finsterer J. Treatment of immune-mediate, dysimmune neuropaties. Acta Neurol Scand 2005;11:115-125.

5. Elovaara I, Apolostolski S, van Doorn P, et al. ENS guidelines for the use of immunoglobulin in treatment of neurological diseases: EFNS taskforce on the uses of intravenous immunoglobulin in treatment of neurological diseases. Eur J Neurol 2008;15:893-908. 